toms transitional societies to military operations in the civil realm, and thus undermines the process of democratization. ${ }^{44}$ Alternatively, external military forces might spread the norms of good civil-military relations if they are aware of the weight of their example and know how to conduct themselves appropriately. ${ }^{45}$ This article has shown the emerging context in which that assumption plays out, and some of the challenges to such leadership by example.

\section{Conclusion}

When we distinguish among types of missions and identify the types of civil-military relationships that are relevant in

44 For the argument that external military involvement increases military operations of local armies and undermines democratization, see Joy Olson and Preston Pentony, US Military Humanitarian and Civil Assistance Programs and Their Application in Central America, Albuquerque, New Mexico: Interhemispheric Resource Center, 1995

45 The latter view has been an underlying assumption in United States civic action programs. See various chapters in John W. de Pauw and George A. Luz, eds., Winning the Peace: The Strategic Implications of Military Civic Action, New York: Praeger, 1992. peacebuilding, it is clear that the character of the mission and the mix of civil-military organizational components require better conception in both planning and execution. Command and control arrangements of multilateral peacebuilding forces are significant to both civil-military relations and the prospects of peace. However, more nuanced division of labor issues arise. The division of labor among civilian and military institutions of contributing states must be resolved by interagency agreement and the determination of a »lead agency." The division of labor between civilian and military institutions at the international level involves not only determining roles of multilateral militaries, but also those of civilians of international and non-governmental organizations. Finally, societies attempting to rebuild after war will be making their own decisions about the division of labor between civilian and military institutions as they transform their own security sector. It is imperative that, as external implementers seek to provide war-torn societies space to make such transformations, they do so with care to the example they set in the process.

\title{
The civil-military interface with local populations: Impact on peacebuilding strategies
}

\author{
Ann M. Fitz-Gerald*
}

\begin{abstract}
Multinational troops are increasingly deployed to internal wars characterized by multiethnic violence, paramilitary regimes and autocratic state leadership. Their closeness to the local populations presents interesting implications for contemporary peacekeeping training programs and the further development of military doctrine in warfighting, peace enforcement and peacekeeping environments. In most cases, regional paramilitary forces and warlords garner local support by convincing indigenous populations that their allegiance will be rewarded with the provision of individual security and protection. The success of the multinational forces in redirecting this allegiance depends largely on how the force is perceived as a credible security provider. For this reason, a careful balance must be preserved between maintaining a »robust posture« and interfacing within the local population to strengthen confidence-building measures.
\end{abstract}

Key Words: peacekeeping, peacebuilding, peace enforcement, multinational military interventions, coalition forces, military culture

$\mathrm{M}$ ilitary intervention through multinational peace support operations has become increasingly challenging due to the complex environments and the many different players that are brought into theatre. Whereas the prevailing model represents a major departure from the former »buffer-zone« peacekeeping, where warring factions were separated by a demarcation zone, nowadays it

\footnotetext{
* Ann Fitz-Gerald is an Associate Professor in the Department of Defence Management and Security Analysis at Cranfield University, UK. She worked in the Canadian Liaison Office at NATO Headquarters in Brussels, Belgium, and has field experience in Angola, Sudan, Sierra Leone, all Former Yugoslav Republics and Colombia, among others.

This article was prepared for the United Nations University-IFSH project »The Role of the Military in Post-Conflict Peacebuilding. "The author ac"The Role of the Military in Post-Conflict Peacebuilding." The author ac-
knowledges the project directors Hans-Georg Ehrhart (IFSH) and Albrecht Schnabel (swisspeace), the members of the project team as well as two anonymous peer reviewers for their input in the preparation of this article.
}

is quite commonplace for indigenous populations to live in close proximity of the intervening military forces and, as such, are able to view their behavioral conduct and operational effectiveness. A common method used by warlords, nonstate actors and paramilitary regimes in garnering the support of local communities, is to offer security guarantees in exchange for their support. As a result, the main task for the international community in responding to these conflicts involves determining the basis for local support and seeking to redirect the population's allegiance towards the interventionist forces by demonstrating the provision of credible security. This is all the more important as research indicates that disparate national approaches observed in recent multinational peace support operations have had a di- 
rect impact on the intensity and duration of conflicts, due to a failure to build sufficient confidence measures at the grass roots level of society.

This article discusses the relationship between local populations and multinational military forces and examines why different behavioral approaches and conducts are key considerations when striving to achieve increased multinational interoperability on the ground. It draws on some national disparities observed in Bosnia and Haiti and explores the potential causes of these differences at the international, national and in-theatre levels. Lastly, the article discusses recent initiatives aimed at minimizing the differences, and the impact this should have on defense policy and military leadership at all levels.

\section{The importance of local dynamics}

Past classic peacekeeping interventions have relied on Chapter VI UN Charter principles of consent, impartiality and the non-use of force except in the case of self-defense. ${ }^{1}$ These principles and procedures have applied to many other interventions, as far back as the 1956 UN Emergency Force (UNEF) deployed to the Sinai, the UN Force in Cyprus (UNFCYP), which is still stationed there today, the $1992 \mathrm{UN}$ Protection Force (UNPROFOR) in Bosnia, the 1993 UN Preventive Deployment (UNPREDEP) in Macedonia and the UN Mission in Sierra Leone (UNAMSIL). These types of operations are most appropriate for the issues discussed in this article due to the restrictions imposed on the troops, and the tasks they are expected to perform.

Chapter VI mandates are most common during the earlier and later stages of a conflict. If a conflict or humanitarian emergency deteriorates to the extent that more robust military action is required, a new mandate is usually issued under Chapter VII of the UN Charter, which authorizes the use of force. ${ }^{2}$ The ratification process behind approving the more robust UN mandate has proven difficult in the past, particularly if it triggers sensitivities for those permanent five UN Security Council members who have the ability to exercise a veto. Such a scenario prevailed during early talks on the deployment of military troops to Kosovo, and the subsequent decision for the Organization for Security and Co-operation in Europe (OSCE) to initially lead the monitoring mission due to the dual veto exercised by both China and Russia. ${ }^{3}$ Alternatively, the entire operation can be taken over by a »coalition of the willing « or a unilateral singlenation intervention. The American and British-led »coalition of the willing « in the 1990 and 2003 Gulf Wars, as well as the 1994 US-led Operation Restore Democracy in Haiti, all serve as respective examples of these arrangements. Thus, it is possible to categorize contemporary conflict interventions into the following three types: 1) a UN-sanctioned/UN-led operation (including by regional organizations), 2) a UN-

1 See Charter of the United Nations and Statute of the International Court of Justice, United Nations: New York, 1994, p.19.

2 Ibid., p. 22.

3 Michael Evans, »Eyes in Sky will back unarmed peace terms, « The Times, London, 14 October 1998, p. 13. sanctioned intervention led by an »executive agent « or 3) a small »coalition of the willing. « The American-led coalition that launched air strikes on Taliban military strongholds in Afghanistan on 7 October 2001, underlines another recent utility of »coalition warfare.«

When security and stability return and humanitarian activity resumes, a new UN mandate that upholds the same Chapter VI principles underwrites the new phase of operations, such as the UN Mission in Kosovo (UNMIK) - the civilian mission that followed the more robust NATO-led enforcement phase and the drafting of UN Resolution 1244. During this later phase, international troops are expected to perform a more integral role within the local society and assist in peacebuilding programs, security sector reform and democratic development. There are many practical initiatives that can help to foster trust and credibility and remove the deeply rooted fear that helped sustain the status quo ante. While it is beyond the scope of this article to acknowledge all possible measures, recommendations that address this problem from a military doctrinal and training perspective will be explored. The following examination draws on research carried out in 1996 in Haiti during the third UN mandate, and during the Stabilization Force (SFOR) deployment in Bosnia. The choice of cases reflects the contemporary nature of conflict, which includes a spectrum of activities from low-intensity warfighting to more tranquil peacebuilding tasks.

\section{Haiti}

The Haitian kleptocratic nature of governance survived until the end of the Duvalier legacy in 1986, followed by a series of similar regimes and bloody coups that lasted for four years. ${ }^{4}$ In December 1990, the Roman Catholic Priest JeanBertrand Aristide was sworn in as President following free and fair elections. A military coup d'état, led by senior military officials and the capital city's chief of police, interrupted his term six months later. Following US-led efforts to broker an agreement for the return of President Aristide and the military regime's non-compliance towards its implementation, a UN-sanctioned/US-led force mandated under Chapter VII of the UN Charter was sent in to restore peace.

The mandate of the operation authorized the US force to use whatever means necessary to return President Aristide to office, in accordance with the Governors Island Agreement. On 31 March 1995, the force was replaced by the UN Mission in Haiti, a multinational peacekeeping force acting under Chapter VI of the UN Charter. The force was tasked with maintaining a secure and stable environment, assisting in the training of a new national police force, and facilitating a free and fair electoral process. ${ }^{5}$ In 1996 the force was downsized and renamed the UN Support Mission in Haiti (UNSMIH). It was supported primarily by Canadian and Pakistani peacekeeping battalions, a French Gendarmerie

\footnotetext{
4 For an excellent overview of the Duvalier legacy, see Elizabeth Abbott, Haiti: the Duvaliers and their Legacy, London: Robert Hale, 1988. 5 UNSCR 867.
} 
contingent and others participating in a UN Civilian Police Force (UNCIVPOL). A small group of American Army logisticians also provided support and were stationed at an airport compound. Its task was to assist in the professionalization of the national police force and in the maintenance of a secure and stable environment.

Research carried out during the UNSMIH deployment examined whether or not different national military conduct and behavior had an impact on the local population's impression of the UN Force. Interviews were conducted on the streets, in restaurants and cafes, in the prisons, municipal offices, at the local police stations, in the more rural areas, and in the aid agency and military compounds. Views were gathered from the local inhabitants and international personnel assisting in all phases of the operation. Although this information was collected during the UNSMIH deployment in the spring of 1996, feedback on national military troops also included those who participated in earlier phases of the intervention.

Feedback on the American troops was divided according to time periods: during the earlier Chapter VII operation that authorized the use of force and the later support role the forces contributed to the UN Force. People generally felt that the American military was the right force to bring in during the earlier days of the conflict, as a lightly-armed peacekeeping force would not have deterred the violence, crime and political unrest. This was particularly the case for the people interviewed in Port-au-Prince where the worst violence was erupting.

In the northern city of Cap Haitien, the American response to a particularly violent firefight with the paramilitary group Force Armee d'Haiti (FAD'H), resulted in increased support for the national troops in areas outside of the capital city. In the incident American warning shots to deter a gang member from shooting a pro-Aristide demonstrator outside the Cap Haitien police station, were answered with direct fire towards the American troops. In response, the Americans shot and killed ten of the paramilitaries. The response to the incident strengthened support for the Americans for at least two reasons: First, it demonstrated to young potential paramilitary recruits that similar behavior would not be tolerated, and it showed the disincentives of subscribing to the cause. Second, residents of Cap Haitien commented on the renewed confidence instilled by the American action, which led to the reopening of local businesses that had been continually looted and robbed by the paramilitaries. For the majority of people in Haiti, any extra income besides state allowances was usually made from market stalls in the city and town centers, and thus the American performance had brought hope that the markets could function once again. One former mayor even suggested that the robust, resolute approach proved to many people that the American's current involvement in Haiti was different from the nationbuilding tactics used between 1915-1934, which had generated so much resentment towards the US. ${ }^{6}$

6 Based on discussions with Mr. Ti Don Moore, Cap Haitien, 9 May 1996
Interviews were conducted with a broader sample set once the UN took over the operation. Local Haitians living around Port-au-Prince grew to resent the American military forces for their insistence on using dedicated military vehicles (and not the open-sided UN trucks used by the other national battalions). Moreover, the locals questioned the need for the tall heavily manned guard towers that the American forces had constructed at each of their sites, and the requirement to travel in groups of no less than eight with heavy military vehicles. This approach during a more peaceful environment had a compelling psychological impact on the Haitian population and magnified the understanding of the UN presence.

The Pakistani battalion, which had been deployed since the transition to the UN force in 1994, had seemingly developed a good rapport with the local groups. Many of those interviewed commented on the Pakistanis' determined look, the positioning of their guns and their attentiveness during patrolling activities, which made the Haitians believe that the Pakistanis were very much aware and in control of the situation. Their ability to combine this structured approach with constant interaction with people, whether it was helping someone push a wheel-barrel down the street or building a soccer field for the children in a bad neighborhood, built tremendous support for the Pakistani battalion in Haiti. People acknowledged that this more than made up for their inability to communicate in the local language. The vast majority of people interviewed were convinced that, had any violence broken out, the Pakistanis would have resisted aggression and protected the population.

The Canadian forces serving in Haiti had inherited an unfortunate legacy of problems from incidents of misconduct in both Somalia and Rwanda. Due to these past experiences, the continuous need for the Canadian armed forces to be seen as politically and militarily »correct « had placed enormous restrictions on the operational capability of the individual serving soldiers. In Haiti, shortly after the transition to the UN-led operation in 1995, Canada was forced to modify its interpretation of the UN rules of engagement (ROE) in order to protect a group of Canadian hydro workers deployed to restore electricity to the capital city of Portau-Prince. ${ }^{7}$ When a warehouse in which they were working came under paramilitary fire, Canadian troops had to request permission to use force to deter the attack. The existing Canadian ROEs only permitted the troops to use force »in the case of self-defense « due to Canada's insistence on the removal of the words »...and in defense of property « prior to deployment. The ROEs were later modified to include "and also in defense of the mandate « which could justify the protection of Canadian civilians. Most countries already use this text despite the Canadian belief that ambiguity in determining what would and would not threaten the mandate may result in unnecessary violence. ${ }^{8}$

The restrictions on the Canadians were obvious even to the local inhabitants. Comments suggested that the Canadian

7 Based on discussions with Colonel Mike Schnell, MA to the Canadian
Permanent Representative to the United Nations, New York, 7 May 1996. 8 Ibid. 
troops tended not to hold their guns at the ready position like their Pakistani and Bangladeshi counterparts, tended not to patrol in the bad areas and demonstrated an inability to defuse and control several street-riots and student protests. On the other hand, almost all of the respondents appreciated the kindness showed by the Canadian military forces and the ease of communication through French cultural and linguistic affinities. However, in the case of a heightened security alert, the confidence they had in the Canadians as credible security providers was quite low.

Only ten years later, the world is now witnessing the recurrence of problems in Haiti. The renewed armed protests against what rebel forces labeled as a lack of democratic governance demonstrated by the recently ousted Aristide regime has led to violent skirmishes in the cities of Port-auPrince, Gonaives and Cap Haitien. Once again, the international community has offered an inadequate at worst, and short-term at best, solution to the problems. Distracted by events in the Middle East, the United States sent approximately 1000 troops to deal with the civil problems, but with the Pentagon's uncategorical statement that the deployment would be short-term only. ${ }^{9}$ Canada, another partner from the past, has also committed to an embarrassing 90-day deployment, despite its large Haitian population and the motivation that led to its commitment in the mid 1990s.

Whatever the separate national motivations and agendas, the response to the problems in Haiti this time must be backed by a longer-term strategy and military credibility that will encourage a sustainable peace in the longer term. Indeed, such a solution will also require regional ownership, and a commitment from organizations like the Caribbean Community (CARICOM), whose members' national interests are all affected by the conflict in Haiti, the strategic transiting it offers to the region's narcotrafficking problem and the scores of refugees that flee to the neighboring island states.

\section{Bosnia}

As the fighting in the former Yugoslavia spread and the situation deteriorated, combined with several failed attempts at brokering a diplomatic solution, measures were increased to bring in NATO involvement and, with it, a more robust mandate. After the signing of the US-brokered Dayton Peace Accords NATO deployed the Implementation Force (IFOR) in December 1995. Since the agreement was brokered, a NATO Stabilization Force (SFOR) has remained in Bosnia. There are three area commands, all of which answer to a central command in Sarajevo. While SFOR represents a UN-sanctioned/NATO-led force subject to the authority of the NATO commanders, it is still deployed in a peacekeeping/peacebuilding capacity and is therefore expected to carry out the rebuilding and reintegration role inherent in post-conflict operations.

9 Author Anonymous, »Haiti After Aristide: Will the Americans finish the job this time? «, Economist, 4 May 2004, p. 9.
Not surprisingly, the Canadian troops left a similar impression in the minds of certain Muslim, Croat and Serb groups in Bosnia. Local residents were interviewed in and around Sarajevo, in the Bihac region of southwest Bosnia, and in the Central Bosnian towns of Gornji Vakuf and Jajce. Canadians had served in all these regions during different phases of the UN and NATO intervention in the former Yugoslav Republic.

Several Canadian soldiers recalled a well-known incident that occurred in April 1998 in the central Bosnian town of Drvar. During the repatriation of Serb groups back to the now Croat-dominated town, the Croat residents of the area rebelled and ignited riots on the streets. The reactions of many Canadians were described as being »confused « and »fearful.« This apparently became more evident when many of the troops jumped back into their SFOR trucks in hope that the problems would die down. British troops, dressed in armor, came in shortly after and secured the area. Many Croats and some Serbs said that, at the time, they were very happy to see the arrival of the British troops.

For a number of reasons, in most areas Serbs did not warm up to American ground troops: When diplomatic efforts reached an impasse during the UN deployment in 1993, the American support for the »lift and strike " option caused some degree of resentment. Moreover, in various press releases and official statements visiting US officials rarely acknowledged the problems caused by the Muslim and Croat populations in Bosnia. This was particularly the case when the Serbs received strong condemnation by the US in the February 1994 mortar incident in the Sarajevo market despite the fact that incident reports analyzing the projection and impact of the firing questioned Serb responsibility.

Most military personnel living and serving in Bosnia were aware of the "heavy " approach used by the Americans when serving on the ground. In Bosnia, inquiries into the travel plans of American troops at checkpoint stops were often met with soldiers jumping out of heavily armed military vehicles in order to guard the spokesperson while he or she dealt with factional representatives. This top-heavy approach, particularly during the SFOR mandate that focused on peacebuilding and reconciliation, was viewed as unnecessary and only served to raise anxieties among the illinformed, and aggravate others. As in Haiti, the troops never traveled in groups of less than eight people with a minimum of two armored personnel carriers. Local residents believed that the Americans had little interest in speaking and interacting with them. When the 1997 riots broke out and demonstrations were mounted in front of the SFOR CivilMilitary Centre in Prijedor, which, at that time, was manned by American officers, the Americans refused to come out and speak to the locals or make efforts to defuse the situation.

Bosnian Muslims living in the Bihac region recalled an incident that further underscored the American's reluctance towards understanding local dynamics. A number of American soldiers had been tasked with distributing IFOR newsletters (a peacebuilding tool used to improve communications and 
understanding) to the area of Bos Krupa. The newsletters were translated in slightly different dialects and emphasized slightly different issues, depending on whether the target audience was Serb, Muslim or Croat. Both the interpreters and a substantial number of local residents realized that little care was being taken towards the distribution of the material and that certain ethnic groups were not receiving papers translated into their own dialects. This indifferent and detached attitude, which was exhibited on many occasions, undermined ethnic sensitivities and did not help the Americans garner support in a very ethnically mixed region. Other troop contingents were more successful in winning the »hearts and minds « of the local population, primarily by demonstrating greater commitment to local needs.

Another incident in 1995 in the Bosnian town of Doboj witnessed a group of Bosnian Muslims being granted permission by Danish and British troops to cross a bridge to visit a cemetery (in the newly proclaimed Serb side of town) where relatives had been buried. Riots broke out and Serbs began chasing Muslims, throwing stones and physically beating them. As the British and Danish troops fired warning shots into the air, their efforts were overshadowed by the sudden appearance of American gunships, with blades tilted downwards in order to spray stones and objects into the air in an »overkill« effort to move back the crowd. Many of the local residents who were interviewed felt that the use of gunships sent a very powerful message to the factional militant groups in terms of consolidating more resources and heavier equipment. Other individuals felt that the Americans were trying to use »scare tactics « to increase compliance in the area.

Due to the broad range of national troop contributors that served in Bosnia between 1995-99, the local populations identified several other national tendencies that affected their perception of the international effort. The behavior of the Bangladeshi and Malaysian soldiers towards Bosnian women and the significant time they spent in local bars and restaurants had affected IFOR's reputation in both Sarajevo and Bihac. While the locals warmed up to the Italian and Spanish troops in the more southern area of Mostar, they feared that they were not capable of offering sufficient protection in the case fighting would re-ignite between the Croat and Muslim factions in the area. Residents in and around Sarajevo and Mount Igman also felt very strongly like the French Foreign Legion's »over the top« approach to »spraying bullets in response to a branch breaking in the wind.«

The results show that various categories of military professionalism were observed in Bosnia. On one end of the scale were troops described as »net users « as opposed to »net contributors « of security. These included the Malaysians, Jordanians, Bangladeshis and Ukrainian troops. Grouped in the next category were troops such as the Spanish, the Dutch and the Canadians. These groups were known to practice softer and less robust soldiering, which would prove ineffective during periods of heavy violence. Their approach was such that they exhibited »static patrolling, « as opposed to »active patrolling, « which suggested to local residents that if problems resurfaced in the future, they would not feel adequately protected by these troops.

The French and Czech forces generated fairly positive feedback on their military conduct and professionalism. Locals from all ethnic backgrounds felt safe in the company of Czech troops and applauded their way of handling tense situations, which was impressive considering the fact that they were still adjusting to Western military practices.

The Americans were criticized for their »top heavy« approach, particularly during times when such an approach seemed unnecessary. They were also described as being insular and non-committal towards understanding and interacting at the local level. Generally speaking, Americans should not be used in such sensitive environments where relationship building and positive encouragement are considered priorities. This has implications for a country whose technological superiority and projection of military power excels at the highest diplomatic and operational levels. Perhaps there is significant merit in John Hillen's argument that »superpowers don't do windows, « which recognizes that NATO best serves its many different security roles by playing to the core competencies of its members, ${ }^{10}$ which, for the United States, should perhaps not include Chapter VI peacekeeping in complex environments.

Local residents applauded the firm approach taken by British troops and their impatience towards obstructionism. However, they also felt that the troops demonstrated a firm commitment to understanding local circumstances in each community and made efforts to remain informed at all times. Individuals and groups seemed very aware of the help that the British troops provided to other forces and were cognizant of the leadership roles they assumed in different multinational situations.

There are obviously many other incidents that may be investigated to assess the collective impact of different national military approaches on a conflict population. However, such preliminary observations recognize that inconsistent and incongruent national interpretations of multinational military procedures, conduct and leadership required to fulfill a mandate can have a negative impact on the overall effort.

Nor can different national contributors be heavily faulted for fine-tuning rules of engagement according to their own national law. Notwithstanding the fact that multinational forces often operate under the control of a regional organization or the UN, donor nations will never be willing to have their forces governed (and held legally accountable) to a standard that is not in accordance with the donating country's domestic law. But when it is known that national legal constraints and political pressure will disturb the multinational unity to the extent that it has a negative impact on the peace process, restrictions should be communicated and core competencies should be more clearly defined. Arguably, the reality of coalition warfare has already advanced

10 John F. Hillem, »Peacekeeping is Hell«, Policy Review, Autumn 2001, p. 17. 
to the point where national exceptions to the force ROEs are accommodated - however, it is questionable whether or not the UN's very political and ad hoc approach to organizing Chapter VI peacekeeping forces is familiar with this.

\section{Implications for multinational military training}

Current multinational training programs neither address the gap in developing standard approaches and uniform interpretation, nor do they provide adequate resources to tackle the problem in the near future. Five years ago the UN was stripped of its "gratis program « under the aegis of the UN Department of Peacekeeping Operations (UNDPKO), whereby an increasing number of military staff officers from the armies of the member states were assigned on loan, or "gratis, « to UNDPKO. Financial limitations imposed on the less industrialized nations to fund officers employed in New York City prompted a call for an expeditious phasing out of all "gratis « personnel, which left UNDPKO with a staff complement that had been reduced from twenty-seven to four.

After successive years of seeking to »train the trainers, « leading military nations within the UN indicated that only a limited number of member states sent designated »trainers« on these courses. Certain national representatives felt that their own training modules were more up to date and reflected current operational requirements for multinational interventions much better than the UN-sponsored course.

However, since 1999, considerable efforts have been made to remedy the training conundrum. Over the past decade, a wave of International Peacekeeping Training Centers has developed, all of which have been organized under the broader International Association of Peacekeeping Training Centers. This has encouraged some degree of standardization and complementarity. The UN's Department of Peacekeeping Operations' Training and Evaluation Service (TES) was set up to develop and devise practical peacekeeping training guidance and strives to advise the UN system on peacekeeping training, develop peacekeeping training material and support operational peacekeeping exercises. The organization employs a multinational staff of over 20 serving military personnel and civilians and thus has helped fill an important gap that was left following the demise of the »Gratis Military Officers « (GMO) program. Other initiatives have arisen, including UNITAR's Program of Correspondence Instruction (POCI). The program serves as training designed to acquaint students with UN peacekeeping missions, particularly those that go on to serve on UN peacekeeping missions. The training underlines the importance of standardized approaches to peacekeeping and is available to both civilians and military personnel at very nominal costs. ${ }^{11}$

However, as the more tranquil Chapter VI peacekeeping operations tend to follow a period of warfighting or more robust enforcement, it has become increasingly apparent that national contributors on the ground during the initial

11 See http://unitarpoci.org. phases of a Chapter VI environment are often not troops that subscribe to UN peacekeeping training. Therefore, however current TES's material and doctrine development may be, local authorities and civilian populations in conflict theatres are often not guaranteed a seamless transition of the operational application of peacekeeping theory between incoming (Chapter VI) and outgoing (Chapter » $61 / 2$ « or VII) troops.

Concepts and doctrine that embrace the more contemporary principles of peacekeeping are articulated in the NATO doctrine for peace support operations. The growing preeminence of this doctrine, and its influence in Europe and the US, is also encouraging a degree of apathy towards UN peacekeeping concepts and training. As the declared »custodian « for NATO doctrine for peace support operations, the UK has been hugely influential in shaping recent military training programs in all of the NATO and associate member states. It recognizes the complex evolution of peace support operations and how different contingencies affect the response requirements. The doctrine also acknowledges the vast number of civilian agents and the continuum along which transitional management and lead-agent responsibilities become exceptionally important.

There is still a significant divide between countries that subscribe to the NATO doctrine, and those who are still loyal to the UN's more conservative and, arguably, outdated approach. ${ }^{12}$ European Defense analysts might argue that NATO's lead on military training is more appropriate, considering its recent involvement as lead agency in peace support operations in the Balkans. None the less, it is imperative that the international community decides which organization should take the lead in training future multinational forces, and that it recognizes that softer, more traditional peacekeeping principles cannot be definitely separated from more robust postures.

However, while such disparities in military conduct remain, efforts at the national and bilateral levels may be the best step forward. Both doctrine and training are important functions of ethical military leadership and, where troops serve in multinational theatres of operations, commanders must realize that different national interpretations can result in disparities within an agreed series of legal responses and procedures. In addition, they must also understand the impact these differences have on the progress towards peace. Benchmarking the best practice of different national contributions in different situations and undertaking appropriate cultural analysis and cultural appreciation training would be an effective way of improving the flexibility and readiness of multinational troops. It would also allow them to move more effectively up and down a »continuum of responses « and adapt to sudden environmental changes, such as a peace enforcement operation that follows a fairly tranquil period of traditional peacekeeping.

As the multinational military coalition in Iraq approaches the last two months before the official political handover to

12 At the time of last revisions to this article (March 2004), UNDPKO has been working on its own doctrine, which may soon fill this gap. 
the Iraqi authorities, different national military approaches are beginning to have an impact on the degree of insurgent activity around key areas, as well as on confidence building measures that the coalition had sought to build. Americanled responses to the recent insurgent activity around the Iraqi towns of Fallujah and Najaf have been described as »top heavy« and not proportionate to the threat. In response to the heavy shelling of the town's main mosque and religious center, former UK Foreign Secretary Robin Cook said of the Americans: »Whenever they fly over these townships and fire missiles into these townships, the are convincing everyone that they are the enemy...we need to try to adopt a policy of peacekeeping and minimum force and try to defuse the situation rather than letting the situation spiral out of control. ${ }^{13}$

Meanwhile, in the more southern regions of Basra and Azzubayr Port, the British Army's »soft walk but with a big stick « approach seems to be boding a bit better. No doubt, the relevance of principles taken from post-colonial and Northern Ireland "policekeeping « experiences carry great applicability in response to the security vacuum in Iraq. General Sir Michael Jackson, current UK Chief of the General Staff summarized this approach with the following comment: »We must be able to fight with the Americans. This does not mean that we will fight as the Americans. « ${ }^{14}$

\section{Conclusion}

This article has examined the realities and uncertainties of current conflict landscapes and the challenges posed to military interventionist forces deployed to these areas. It has also emphasized that, despite claims of a changing future strategic threat, most interventions will almost always include the deployment of ground forces either before, during or after an actual targeted attack. For this reason, it is essential that future policies on multinational military intervention consider the more operational and tactical requirements that are essential for improving cohesion and unity of effort on the ground.

Empirical research undertaken in Bosnia and Haiti underlined the significance of the local populations in these areas. It also showed that international military conduct must view these groups as the main stakeholders of conflicts and groups that are key to a sustainable peace. If, through inconsistent behavior and disparate approaches of multinational troops, the local groups re-evaluate their allegiance to the international effort, they may easily fall vulnerable once again to the forces that ignited the conflict in the first place. Once this happens, the prospect of a sustainable peace becomes more uncertain and the task of the interventionists becomes increasingly difficult.

The UN has struggled to develop effective doctrine and training programs for peace support operations and, despite

13 Robin Cook: »Iraq Strategy is Failing «, Guardian, 8 April 2004, p. 2

14 Richard Norton-Taylor, »General Hits out at US tactics«, The Daily Telegraph, 26 April 2004, p. 2. the ambitious recommendations laid out in the Brahimi report, progress remains slow at best. While the UN has taken the lead on several initiatives, such as the UN Training and Evaluation Service (TES) and the UN Institute for Training and Research's (UNITAR's) Program of Correspondence Instruction (POCI), research must examine ways in which these efforts may be more marketable to leading peacekeeping nations and to countries that contribute to more robust phases of peace support operations.

The growing pre-eminence of NATO doctrine and its influence in Europe also encourages an increased ambivalence towards UN programs. If the gap between the »NATO subscribing countries « (for example, United Kingdom, United States and France) and the »UN subscribing countries « (for example, Nigeria, Bangladesh, Malaysia) is left to widen even further, the impact will be felt most when ground troops are attempting to »keep« a peace and run extensive peacebuilding programs to maintain it. This marks the critical period when troops interact closely with the local populations and must use confidence-building measures to sustain their support.

In the wake of recent calls to improve multinational interoperability between allies, research should be undertaken to explore the "positioning « of different national troop contributors in terms of manpower, fighting power, capability, and deployability, with the cultural mindset and public and political support each nation brings to a theatre. Such a study could further categorize nations into broader categories, perhaps labeled as »front line, « »second line« or »support line« peace interventionists. As each country finds its position and establishes the goals it must pursue to achieve multinational interoperability with its allies, benchmarking the successful approaches and conduct of »like« countries may help them to reach their objectives and, more importantly, improve unity of effort in difficult and challenging circumstances. 